УДК 634.8.

DOI 10.30679/2219-5335-2020-1-61-67-83

ПРИМЕНЕНИЕ МАТЕМАТИЧЕСКИХ ПОДХОДОВ В АМПЕЛОГРАФИЧЕСКОМ ИССЛЕДОВАНИИ ДЕСЕРТНЫХ СОРТОВ ВИНОГРАДА, ВЫРАЩИВАЕМЫХ В ЮЖНОЙ БОЛГАРИИ

Керанова Н. д-р

главный ассистент

кафедры математики и физики

Ройчева А., д-р

ассистент кафедры экономики

Иванов А., д-р, доцент

Ройчев В., д-р с.-х. наук

профессор кафедры виноградарства

Аграрный университет,

Пловдив, Болгария

Янева В., д-р

директор питомника

Милко Янев

Исполнительный директор

$O O O ~ « A M B ~ А Г Р О »$,

Пловдив, Болгария

Для теоретического и практического виноградарства всегда представляет интерес информация, связанная с ампелографической характеристикой выращиваемых сортов винограда в конкретных районах, и особенно, когда в неё включены и результаты применения современных математических методов. В данной статье приведены результаты ампелографического исследования десертных сортов винограда, выращиваемых в Южной Болгарии, с использованием современных математических методов анализа. Установлено, что сорт винограда Виктория характеризуется наиболее высоким коэффициентом плодоносности. Процент плодовых побегов самый большой у сорта
UDC 634.8.

DOI 10.30679/2219-5335-2020-1-61-67-83

\section{APPLICATION OF MATHEMATICAL APPROACHES IN AMPELOGRAPHIC RESEARCH OF TABLE VINE CULTIVARS GROWN IN THE SOUTHERN BULGARIA}

Keranova N., Dr. the Main Assistant of Mathematics and Physics Department

Roicheva A., Dr.

Assistant of Economics Department

Ivanov A., Dr., Docent

Roichev V., Dr. Sci. Agr.

Professor of Viticulture Department

Agricultural University, Plovdiv, Bulgaria

Yaneva V., Dr. Chief of Nursery

Milko Yanev

Executive Director

«AMV AGRO»LLC, Plovdiv, Bulgaria

For theoretical and especially practical viticulture, the information related to the ampelographic characteristics of cultivated grape varieties in the specific areas are of interest always, and especially when the results of applying the modern mathematical methods are included. An ampelographic study of table vine cultivars grown in South Bulgaria has been conducted through the application of modern mathematical methods of analysis. It has been found that Victoria grapes is characterized by the highest fertility coefficient. The percentage of fruiting shoots is the highest in Matilda, 
Матильда, а процент развитых угловых глазков - у сортов Русенско Едро и Панс Прекос. Самой большой массой 100 ягод отличаются сорта винограда Палиери, Дунай и Русенско Едро. Доля кожиц в ягодах наиболее высокая у сорта Болгар, а доля семян - у сорта Мискет гамбургский. Наиболее высоким содержанием сахаров в ягодах винограда обладает сорт Мискет гамбургский, а самым высоким содержанием титруемых кислот - сорта Италия и Панс Прекос. Самыми устойчивыми при транспортировке являются сорта винограда Дунай и Италия. Проведённые учёты показали, что урожай с одного куста винограда и с 10 аров самый высокий у сортов Дунай и Виктория. Доминирующее влияние на распределение исследуемых сортов в кластеры, в зависимости от их генетической удалённости, имеют показатели, обладающие максимальным факторным весом коэффициент плодоносности, процент плодовых побегов, масса 100 ягод, величина силы отрыва ягоды и урожай винограда. Полученные результаты могут быть использованы в агротехнике и селекционной работе с десертными сортами винограда.

Ключевые слова: ДЕСЕРТНЫЕ СОРТА ВИНОГРАДА, АГРОБИОЛОГИЧЕСКИЕ И ТЕХНОЛОГИЧЕСКИЕ ПОКАЗАТЕЛИ, МАТЕМАТИЧЕСКИЕ ПОДХОДЫ, АМПЕЛОГРАФИЧЕСКАЯ ОЦЕНКА and the percentage of angular buds developed - in Rousse Large and Pance Prekos. The greatest weight of 100 berries has been reported in Palieri, Danube and Rousse Large grape varieties. The share of the skins in the berries is the most considerable in Bolgar, and the share of seeds in the Muscat Hamburg. The sugar content of grape berries is the highest in Muscat Hamburg, while the titratable acids are the highest in Italy and Pance Prekos. Danube and Italy grapes are the most suitable for transportation. The study carried out has been shown that the yield per vine and per decare is the greatest in Danube and Victoria. A dominant influence the distribution of the studied cultivars into clusters, according to their genetic remoteness, is exerted by the indicators with maximum factor weight - fertility coefficient, percentage of fruiting shoots, weight of 100 berries, force of berry tearing and grape yield. The results can be used in agricultural technology and breeding with dessert grape varieties.

Key words: TABLE VINE CULTIVARS, AGROBIOLOGICAL AND TECHNOLOGICAL INDICATORS, MATHEMATICAL APPROACHES, AMPELOGRAPHIC EVALUATION

Введение. Производство десертного винограда в Болгарии является традиционным для многих районов, где он выращивается с глубокой древности. Площадь таких виноградников на 2010 г. составляет 3498,94 гектаров - 6 \% всех виноградных насаждений. В 1938 и 1965 годах Болгария занимала первое место в мире по экспорту десертного винограда, главным образом винограда сорта Болгар. Сортовая структура производства десертного винограда менялась в различные периоды развития виноградарства и была объектом непрерывного обсуждения и дополнений [1-6 и др.]. Были созданы и многие новые десертные сорта и клоны винограда, обладающие 
отличными дегустационными качествами, в том числе и устойчивые к болезням [7-11 и др.].

В период 1995-2014 гг. потребление десертного винограда в мировом масштабе возрастает, причём налицо тенденция прогрессивного расширения потребляемых количеств продукта. Среднегодовой темп прироста в мировом потреблении десертного винограда за рассматриваемый период составляет 6,2 \%. Основная причина расширения глобального потребления десертного винограда связывается с увеличением числа мирового населения; либерализацией международной торговли во многих регионах мира; с лучшей информированностью и повышенной культурой потребителей по линии маркетинга относительно ценных качеств этого продукта; с введёнными инновациями в производство винограда, с рядом созданных новых виноградных десертных сортов, отличающихся повышенным потребительским спросом, с глобальным потеплением климата [12]. В тот самый период в Болгарии наблюдается противоположная тенденция спада в потреблении десертного винограда [13].

Для теоретического и особенно для практического виноградарства всегда представляла интерес информация, связанная с ампелографической характеристикой выращиваемых десертных сортов винограда в конкретных районах [14-16], и особенно, когда в неё включены и результаты применения современных математических методов.

Цель настоящего исследования - с использованием математических подходов анализа сравнить агробиологические и технологические качества десертных сортов винограда, выращиваемых в Южной Болгарии.

Объекты и методы исследований. В экспериментальную работу включены десертные семенные сорта винограда Болгар, Дунай, Русенско Едро, Виктория, Италия, Палиери, Мискет гамбургский, Панс Прекос, Матильда, выращиваемые в районе города Пловдив. Плодоносящий возраст 
насаждений - 15-20 лет, виноградные растения привиты на подвой Берландиери х Рипария SO 4, формирование кустов - по типу двуплечего Гюйо, расстояние между рядами при посадке виноградных растений - 2,5/1,2 m. В течение десятилетнего периода определялись следующие агробиологические и технологические показатели, разделённые условно в несколько групп: коэффициент действительной плодоносности, процент плодовых побегов и глазков, развитых из сучков замещения, стрелок плодоношения и т.д.; масса 100 ягод и структура ягод; содержание сахаров, титруемых кислот и транспортабельность винограда; урожай с одного куста и с 10 аров; масса грозди и структура грозди.

Опытные данные обработаны математически с помощью однофакторного дисперсионного анализа и теста Duncan для оценки отличий между сортами по соответствующему показателю.

Генетическая удалённость между включёнными в разработку десертными сортами исследована с помощью иерархического кластерного анализа по методу межгруппового связывания и с использованием в качестве меры близости между кластерами квадратичного евклидового расстояния, из-за максимального коэффициента контингенции.

При этом методе определение расстояний между двумя кластерами А и В осуществляется с помощью формулы: $\quad D(A, B)=\frac{1}{n_{A} n_{B}} \sum_{i=1}^{n_{A}} \sum_{j=1}^{n_{B}} d\left(x_{i}, x_{j}\right)$ где $\mathrm{nA}$ и $\mathrm{nB}$ - количество очков соответственно А и $\mathrm{B}$, $\operatorname{ad}\left(\mathrm{x}_{\mathrm{i}}, \mathrm{x}_{\mathrm{j}}\right)=\sum_{\mathrm{m}=1}^{\mathrm{p}}\left(\mathrm{x}_{\mathrm{im}}-\mathrm{x}_{\mathrm{jm}}\right)^{2}$,

$i, j=\overline{1, n}$ - это квадрат евклидового расстояния между двумя векторами $x_{i}\left(x_{i 1}, x_{i 2}, \ldots, x_{i p}\right)$ и $x_{j}\left(x_{j 1}, x_{j 2}, \ldots, x_{j p}\right)$.

Данные стандартизованы предварительно в целях избежания влияния различных размерностей на исследуемые показатели. Доказано, что они имеют распределение, близкое к нормальному, что является предпосылкой для применения соответствующих анализов. Применение факторного ана- 
лиза на базе экспериментальных данных продиктовано необходимостью качественного описания полученной кластеризации. С его помощью определяются факторы, оказывающие сильнейшее влияние на группирование сортов в кластеры. Для их выявления применён метод главных компонентов, а в качестве метода вращения факторов - Varimax.

Произведена проверка адекватности применённого подхода посредством теста Кайзера-Мейера-Олкина и теста сферичности Бартлетта. Математическая обработка данных проведена с помощью статистического программного продукта IBM Statistics SPSS 23 [17-19].

Обсуждение результатов. Результаты сравнительной оценки десертных сортов винограда показывают, что коэффициент действительной плодоносности у побегов, развившихся на сучке замещения, имеет наибольшие значения у угловых и зимних глазков сорта Виктория $(1,18 ; 1,46)$, а наименьшие - у сортов Панс Прекос $(0,20)$ и Италия $(0,51)$ (табл. 1$)$. При варианте «плодовая стрелка» опять наибольшие значения этого показателя наблюдаются у угловых глазков сорта Виктория $(1,16)$, а наименьшие - $(0,00)-$ у сортов Италия, Панс Прекос и Мискет гамбургский.

Наиболее плодоносны зимние глазки у сорта Мискет гамбургский $(1,68)$, а самые низкие значения этого показателя наблюдаются у сорта Италия $(1,08)$. Средние значения коэффициента плодоносности наибольшие у угловых глазков сорта Виктория $(1,17)$, наименьшие - у сорта Панс Прекос $(0,15)$; у зимних глазков, соответственно, у сортов Виктория $(1,55)$ и Италия $(0,9)$.

Процент плодовых побегов у угловых глазков на сучке замещения наибольший у сорта Матильда $(75,54)$ и наименьший - у сорта Дунай $(16,75)$ (табл. 2). Что касается зимних глазков, значения исследуемого показателя максимальны у сорта Виктория $(84,83)$, а минимальны у сорта Италия $(44,23)$. Наиболее высоким процентом плодовых побегов у угловых и зимних глазков (вариант «плодовая стрелка») обладает сорт Матильда (72,35; $88,30)$, а наиболее низким - угловые глазки сортов Италия, Панс Прекос и Мискет гамбургский $(0,00)$. 
Плодоводство и виноградарство Юга России № 61(1), 2020 г.

Таблица 1 - Сравнительная оценка исследуемых десертных сортов винограда в зависимости от коэффициента плодоносности с помощью однофакторного дисперсионного анализа и теста Duncan

\begin{tabular}{|c|c|c|c|c|c|c|c|}
\hline \multirow{4}{*}{$\begin{array}{c}\text { Кластер } \\
\text { № }\end{array}$} & \multirow{4}{*}{ Сорт } & \multicolumn{6}{|c|}{ Коэффициент плодоносности } \\
\hline & & \multicolumn{4}{|c|}{ Плодовое звено } & \multirow{2}{*}{\multicolumn{2}{|c|}{ В среднем }} \\
\hline & & \multicolumn{2}{|c|}{ сучок } & \multicolumn{2}{|c|}{ плодовая стрелка } & & \\
\hline & & $\begin{array}{c}\text { угловые } \\
\text { глазки }\end{array}$ & $\begin{array}{l}\text { зимние } \\
\text { глазки }\end{array}$ & $\begin{array}{c}\text { угловые } \\
\text { глазки }\end{array}$ & $\begin{array}{l}\text { зимние } \\
\text { глазки }\end{array}$ & $\begin{array}{c}\text { угловые } \\
\text { глазки }\end{array}$ & $\begin{array}{l}\text { зимние } \\
\text { глазки }\end{array}$ \\
\hline \multirow{2}{*}{ I } & Виктория & $1,18^{\mathrm{a}}$ & $1,46^{\mathrm{a}}$ & $1,16^{\mathrm{a}}$ & $1,59^{\mathrm{a}}$ & $1,17^{\mathrm{a}}$ & $1,55^{\mathrm{a}}$ \\
\hline & Матильда & $1,03^{\mathrm{b}}$ & $1,25^{\mathrm{b}}$ & $0,95^{\mathrm{b}}$ & $1,55^{\mathrm{a}}$ & $1,01^{\mathrm{b}}$ & $1,47^{\mathrm{a}}$ \\
\hline \multirow{4}{*}{ II } & Болгар & $0,33^{\text {de }}$ & $0,78^{\mathrm{d}}$ & $0,10^{\mathrm{d}}$ & $1,14^{\mathrm{b}}$ & $0,27^{\text {def }}$ & $1,01^{\mathrm{b}}$ \\
\hline & Италия & $0,21^{\mathrm{e}}$ & $0,51^{\mathrm{e}}$ & $0,00^{\mathrm{d}}$ & $1,08^{\mathrm{b}}$ & $0,16^{\mathrm{f}}$ & $0,90^{\mathrm{b}}$ \\
\hline & Дунай & $0,22^{\mathrm{e}}$ & $0,76^{\mathrm{d}}$ & $0,16^{\mathrm{d}}$ & $1,24^{\mathrm{b}}$ & $0,20^{\mathrm{ef}}$ & $1,06^{\mathrm{b}}$ \\
\hline & Панс Прекос & $0,20^{\mathrm{e}}$ & $0,74^{\mathrm{d}}$ & $0,00^{\mathrm{d}}$ & $1,16^{\mathrm{b}}$ & $0,15^{\mathrm{f}}$ & $1,01^{\mathrm{b}}$ \\
\hline \multirow{3}{*}{ III } & Мискет гамбургский & $0,50^{c}$ & $1,00^{c}$ & $0,00^{\mathrm{d}}$ & $1,68^{\mathrm{a}}$ & $0,38^{\mathrm{cd}}$ & $1,38^{\mathrm{a}}$ \\
\hline & Русенско Едро & $0,42^{\text {cd }}$ & $0,74^{\mathrm{d}}$ & $0,08^{\mathrm{d}}$ & $1,26^{\mathrm{b}}$ & $0,33^{\text {cde }}$ & $1,08^{\mathrm{b}}$ \\
\hline & Палиери & $0,47^{\mathrm{cd}}$ & $0,69^{\text {de }}$ & $0,41^{\mathrm{c}}$ & $1,18^{\mathrm{b}}$ & $0,45^{\mathrm{c}}$ & $1,00^{\mathrm{b}}$ \\
\hline
\end{tabular}

Примечание: a,b,c,d,e,f - степень доказательности при уровне значимости $\alpha=0,05$.

Таблица 2 - Сравнительная оценка исследуемых десертных сортов винограда в зависимости от процента плодовых побегов с помощью однофакторного дисперсионного анализа и теста Duncan

\begin{tabular}{|c|c|c|c|c|c|c|c|}
\hline \multirow{4}{*}{$\begin{array}{c}\text { Кластер } \\
\text { № }\end{array}$} & \multirow{4}{*}{ Сорт } & \multicolumn{6}{|c|}{ Процент плодовых побегов } \\
\hline & & \multicolumn{4}{|c|}{ Плодовое звено } & \multirow{2}{*}{\multicolumn{2}{|c|}{ В среднем }} \\
\hline & & \multicolumn{2}{|c|}{ сучок } & \multicolumn{2}{|c|}{ плодовая стрелка } & & \\
\hline & & $\begin{array}{c}\text { угловые } \\
\text { глазки }\end{array}$ & $\begin{array}{l}\text { зимние } \\
\text { глазки }\end{array}$ & $\begin{array}{c}\text { угловые } \\
\text { глазки }\end{array}$ & $\begin{array}{c}\text { зимние } \\
\text { глазки }\end{array}$ & $\begin{array}{l}\text { угловые } \\
\text { глазки }\end{array}$ & $\begin{array}{c}\text { зимние } \\
\text { глазки }\end{array}$ \\
\hline \multirow[b]{2}{*}{ I } & Виктория & $70,62^{\mathrm{a}}$ & $84,83^{\mathrm{a}}$ & $71,59^{\mathrm{a}}$ & $85,83^{\text {ab }}$ & $71,61^{\mathrm{a}}$ & $85,42^{\mathrm{a}}$ \\
\hline & Матильда & $75,54^{\mathrm{a}}$ & $83,64^{\mathrm{a}}$ & $72,35^{\mathrm{a}}$ & $88,3^{\text {ab }}$ & $76,20^{\mathrm{a}}$ & $86,74^{\mathrm{a}}$ \\
\hline \multirow{4}{*}{ II } & Болгар & $32,54^{\mathrm{d}}$ & $54,83^{\mathrm{d}}$ & $7,52^{c}$ & $74,94^{\text {cd }}$ & $25,9^{\mathrm{d}}$ & $68,01^{\text {ef }}$ \\
\hline & Италия & $20,95^{\mathrm{e}}$ & $44,23^{\mathrm{e}}$ & $0,00^{\mathrm{c}}$ & $71,26^{\mathrm{d}}$ & $15,59^{\mathrm{e}}$ & $61,95^{\mathrm{f}}$ \\
\hline & Дунай & $16,75^{\mathrm{e}}$ & $55,77^{\mathrm{d}}$ & $12,11^{\mathrm{c}}$ & $70,25^{\mathrm{d}}$ & $15,02^{\mathrm{e}}$ & $65,50^{\text {ef }}$ \\
\hline & Панс Прекос & $19,17^{\mathrm{e}}$ & $62,73^{\mathrm{cd}}$ & $0,00^{c}$ & $82,81^{\text {bc }}$ & $14,38^{\mathrm{e}}$ & $75,72^{\text {cde }}$ \\
\hline \multirow{3}{*}{ III } & $\begin{array}{l}\text { Мискет } \\
\text { гамбургский }\end{array}$ & $50,00^{\mathrm{b}}$ & $72,70^{\mathrm{b}}$ & $0,00^{c}$ & $95,33^{\mathrm{a}}$ & $37,5^{\mathrm{bc}}$ & $81,75^{\mathrm{ab}}$ \\
\hline & Русенско Едро & $40,44^{\mathrm{cd}}$ & $65,51^{\mathrm{bc}}$ & $9,05^{\mathrm{c}}$ & $82,50^{\mathrm{bc}}$ & $32,78^{\mathrm{cd}}$ & $76,28^{\mathrm{bc}}$ \\
\hline & Палиери & $45,07^{\mathrm{bc}}$ & $60,56^{\mathrm{cd}}$ & $39,18^{\mathrm{b}}$ & $78,48^{\mathrm{bcd}}$ & $43,45^{\mathrm{b}}$ & $71,62^{\text {cde }}$ \\
\hline
\end{tabular}

Примечание: a,b,c,d,e,f - степень доказательности при уровне значимости $\alpha=0,05$. 
Меньшее количество плодовых побегов, развившихся из зимних глазков, имеет сорт Дунай $(70,25)$. Высокие средние показатели по угловым и зимним глазкам у сорта Матильда $(76,20 ; 86,74)$. В первом случае этот показатель имеет минимальные значения у сорта Панс Прекос $(14,38)$, а во втором - у сорта Италия $(61,95)$.

Высокий процент развитых глазков при обрезке с оставлением сучка замещения - угловых глазков, отмечен у сорта Русенско Едро $(48,03)$, а самый низкий - у сорта Панс Прекос $(18,03)$ (табл. 3).

Таблица 3 - Сравнительная оценка десертных сортов винограда в зависимости от процента развитых глазков с помощью однофакторного дисперсионного анализа и теста Duncan

\begin{tabular}{|c|c|c|c|c|c|c|c|}
\hline \multirow{4}{*}{$\begin{array}{c}\text { Кластер } \\
\text { № }\end{array}$} & \multirow{4}{*}{ Сорт } & \multicolumn{6}{|c|}{ Процент развитых глазков } \\
\hline & & \multicolumn{4}{|c|}{ Плодовое звено } & \multirow{2}{*}{\multicolumn{2}{|c|}{ В среднем }} \\
\hline & & \multicolumn{2}{|c|}{ сучок } & \multicolumn{2}{|c|}{ плодовая стрелка } & & \\
\hline & & $\begin{array}{c}\text { угловые } \\
\text { глазки }\end{array}$ & $\begin{array}{l}\text { зимние } \\
\text { глазки }\end{array}$ & $\begin{array}{c}\text { угловые } \\
\text { глазки }\end{array}$ & $\begin{array}{l}\text { зимние } \\
\text { глазки }\end{array}$ & $\begin{array}{c}\text { угловые } \\
\text { глазки }\end{array}$ & $\begin{array}{l}\text { зимние } \\
\text { глазки }\end{array}$ \\
\hline \multirow{2}{*}{ I } & Виктория & $26,26^{\mathrm{bc}}$ & $84,09^{a}$ & $9,70^{\mathrm{b}}$ & $68,03^{\text {cd }}$ & $20,47^{\mathrm{b}}$ & $73,78^{\text {cd }}$ \\
\hline & Матильда & $29,46^{\mathrm{b}}$ & $88,03^{\mathrm{a}}$ & $16,27^{\mathrm{ab}}$ & $77,91^{\mathrm{b}}$ & $25,35^{\mathrm{b}}$ & $82,40^{\mathrm{ab}}$ \\
\hline \multirow{4}{*}{ II } & Болгар & $22,47^{\mathrm{bc}}$ & $81,62^{\mathrm{a}}$ & $6,24^{\mathrm{b}}$ & $71,92^{\text {bcd }}$ & $17,93^{\mathrm{b}}$ & $\underset{\substack{\mathrm{d} \\
\mathrm{d}}}{75,49^{\mathrm{bc}}}$ \\
\hline & Италия & $27,78^{\mathrm{bc}}$ & $83,45^{\mathrm{a}}$ & $0,00^{\mathrm{b}}$ & $64,44^{\mathrm{d}}$ & $20,70^{\mathrm{b}}$ & $71,11^{\mathrm{d}}$ \\
\hline & Дунай & $43,73^{\mathrm{a}}$ & $85,65^{\mathrm{a}}$ & $15,41^{\mathrm{ab}}$ & $77,82^{\mathrm{b}}$ & $35,52^{\mathrm{a}}$ & $80,38^{\mathrm{bc}}$ \\
\hline & Панс Прекос & $18,03^{\mathrm{c}}$ & $92,43^{\mathrm{a}}$ & $15,00^{\mathrm{ab}}$ & $85,67^{\mathrm{a}}$ & $17,28^{\mathrm{b}}$ & $88,05^{\mathrm{a}}$ \\
\hline \multirow{3}{*}{ III } & $\begin{array}{l}\text { Мискет } \\
\text { гамбургский }\end{array}$ & $40,00^{\mathrm{a}}$ & $87,29^{\mathrm{a}}$ & $0,00^{\mathrm{b}}$ & $67,75^{\mathrm{cd}}$ & $34,29^{\mathrm{a}}$ & $79,48^{\mathrm{bc}}$ \\
\hline & Русенско Едро & $48,03^{\mathrm{a}}$ & $89,15^{\mathrm{a}}$ & $12,98^{\mathrm{ab}}$ & $73,49^{\mathrm{bc}}$ & $39,09^{\mathrm{a}}$ & $79,22^{\mathrm{bc}}$ \\
\hline & Палиери & $46,29^{\mathrm{a}}$ & $84,08^{\mathrm{a}}$ & $27,81^{\mathrm{a}}$ & $70,09^{\text {cd }}$ & $40,04^{\mathrm{a}}$ & $75,13^{\text {bcd }}$ \\
\hline
\end{tabular}

Примечание: a,b,c,d,e,f - степень доказательности при уровне значимости $\alpha=0,05$.

У зимних глазков максимальные значения этого показателя зарегистрированы у сорта Панс Прекос $(92,43)$, а минимальные - у сорта Болгар $(81,62)$, несмотря на то, что отсутствуют доказанные отличия. В варианте «плодовый побег», развившийся из угловых глазков, самое большое количество побегов наблюдается у сорта Палиери (27,81 \%), у сортов Италия и Мискет гамбургский - 0 \%. Процент развитых зимних глазков максимален у сорта 
Панс Прекос $(85,67)$ и минимален у сорта Италия $(64,44)$. Средние значения этого показателя относительно угловых глазков самые высокие у сорта Палиери $(40,04)$ и самые низкие у сорта Панс Прекос $(17,28)$. Последний сорт отличается наибольшим средним процентом развитых зимних глазков $(88,05)$, а сорт Италия - наименьшим $(71,11)$.

Иерархический кластерный анализ группирования исследуемых десертных сортов винограда в зависимости от коэффициента плодоносности и процента плодовых побегов и развитых глазков показывает, что они распределяются в три кластера (рис. 1).

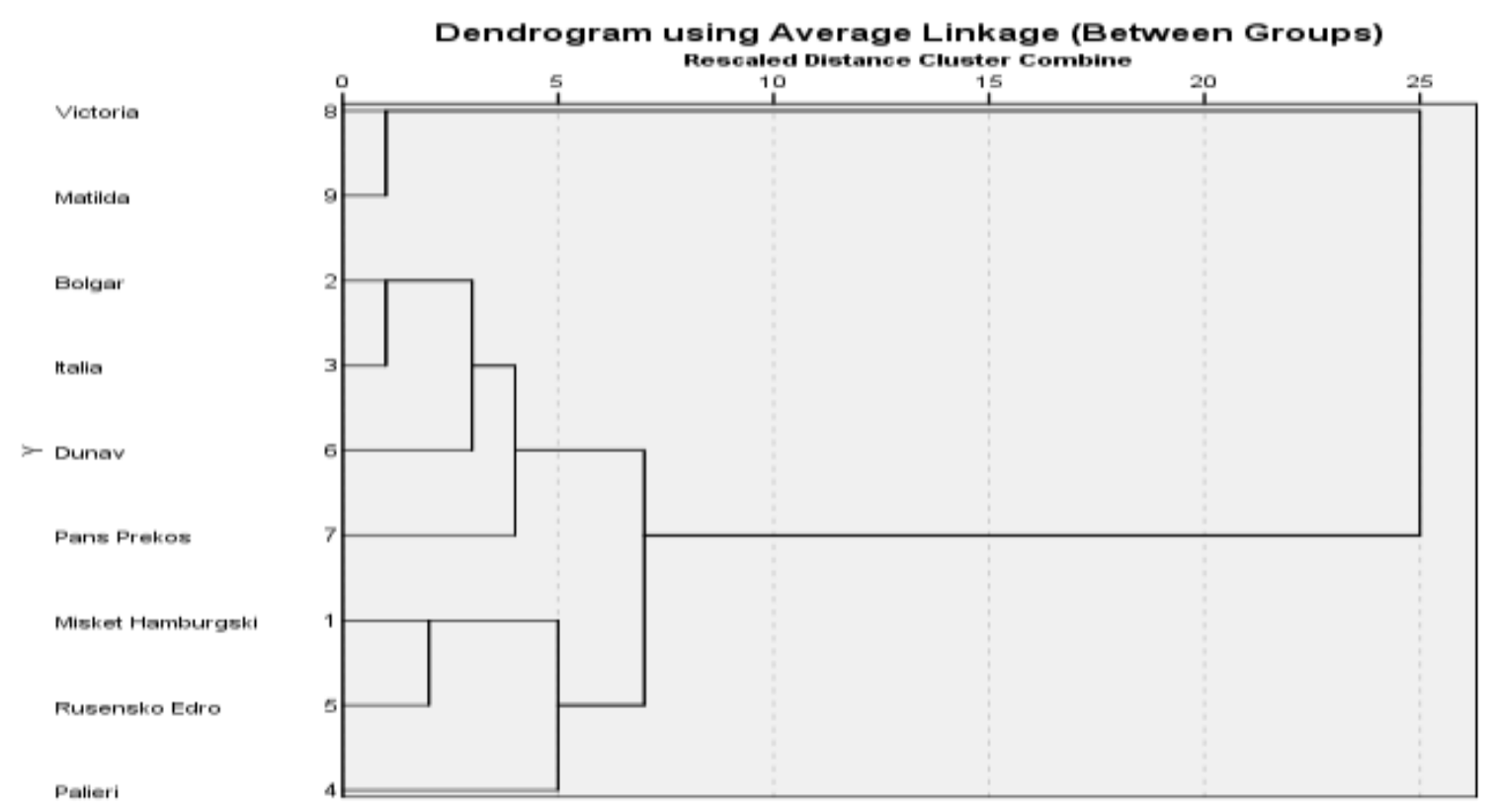

Рис. 1. Дендрограмма - кластеризация исследуемых десертных сортов винограда в зависимости от коэффициента плодоносности, процента плодовых побегов и развитых глазков

Первый включает сорта Виктория и Матильда, выделяющиеся высокими коэффициентами плодоносности и процентом плодовых побегов. Второй кластер состоит из сортов Болгар, Италия, Дунай и Панс Прекос, характеризующихся низким процентом плодовых побегов, развившихся из угловых и зимних глазков на сучке замещения и плодовой стрелке. Третий кластер формируется сортами Мискет гамбургский, Русенско Едро и Палиери, для которых характерен сравнительно высокий процент развитых угловых глазков и низкий коэффициент плодоносности глазков на плодовой стрелке. 
Было доказано, что выполнены необходимые условия для применения факторного анализа относительно каждой из четырех групп показателей (Kaiser_Meyer_Olkin Test $>0,5$; Bartlett's Test of Sphericity < 0,05). После его применения по методу главных компонент исследуемые показатели трансформируются до четырех факторов. Второй фактор включает процент глазков, развившихся на сучке замещения и на плодовой стрелке.

Третий фактор состоит только из процента развитых угловых глазков на сучке замещения, четвёртый - из процента развитых зимних глазков на плодовой стрелке. Все остальные показатели формируют первый фактор, причём наиболее высоким факторным весом обладают коэффициент плодоносности: угловые и зимние глазки, развившиеся на сучке замещения, угловые глазки на плодовой стрелке и сучке замещения, а также процент плодовых побегов, развившихся из зимних и угловых глазков на сучке замещения и, в среднем, из угловых глазков. Первый фактор объясняет 56 \% общей дисперсии, второй $18 \%$, третий - $13 \%$, четвёртый - $10 \%$ (всего $99 \%$ ).

Результаты сравнительной оценки десертных сортов винограда по массе 100 ягод (g) и структуре ягоды (\%) показывают, что у сорта Палиери самая большая масса 100 ягод (774,2 g), за ним идут сорта Дунай $(773,2$ g) и Русенско Едро $(742,7 \mathrm{~g})$, а самой низкой величиной этого показателя обладает Мискет гамбургский (402 g) (табл. 4). Самая большая доля кожиц в ягодах у сорта Болгар (5,76 \%), а самая небольшая у сорта Дунай (3,19 \%). Наибольшее количестве семян в процентном соотношении относительно остальных частей ягоды - у сорта Мискет гамбургский (2,13 \%), наименьшее - у сорта Виктория (1,02 \%). Большим мезокарпием обладают ягоды сорта Панс Прекос (95,1 \%), меньшим - сорт Болгар (92,2 \%).

Исследуемые десертные сорта винограда сгруппированы в три кластера на базе их генетической удалённости по массе 100 ягод и структуре ягоды (рис. 2). Первый кластер включает сорта с самыми тяжёлыми ягодами - Палиери, Дунай, Русенско Едро и Виктория. Второй состоит из сортов Болгар и Италия, имеющих доказанное сходство по массе 100 ягод, а также 
по процентному содержанию семян. Сорта с более легкими ягодами - Панс Прекос, Матильда и Мискет гамбургский формируют третий кластер.

Таблица 4 - Сравнительная оценка исследуемых десертных сортов винограда в зависимости от массы и структуры ягоды с помощью однофакторного дисперсионного анализа и теста Duncan

\begin{tabular}{|c|l|c|c|c|c|}
\hline \multirow{2}{*}{ Кластер № } & \multicolumn{1}{|c|}{ Сорт } & Масса 100 ягод, I & $\begin{array}{c}\text { Кожица, } \\
\%\end{array}$ & $\begin{array}{c}\text { Семена, } \\
\%\end{array}$ & $\begin{array}{c}\text { Мезокарпий, } \\
\%\end{array}$ \\
\hline \multirow{3}{*}{ I } & Палиери & $774,2^{\mathrm{a}}$ & $5,45^{\mathrm{abc}}$ & $1,10^{\mathrm{c}}$ & $93,45^{\mathrm{c}}$ \\
\cline { 2 - 6 } & Дунай & $773,2^{\mathrm{a}}$ & $3,19^{\mathrm{f}}$ & $2,04^{\mathrm{a}}$ & $94,77^{\mathrm{a}}$ \\
\cline { 2 - 6 } & Русенско Едро & $742,7^{\mathrm{a}}$ & $5,56^{\mathrm{ab}}$ & $1,19^{\mathrm{c}}$ & $93,26^{\mathrm{c}}$ \\
\cline { 2 - 6 } & Виктория & $683,7^{\mathrm{b}}$ & $5,11^{\mathrm{bcd}}$ & $1,02^{\mathrm{c}}$ & $93,87^{\mathrm{bc}}$ \\
\hline \multirow{2}{*}{ II } & Болгар & $557,3^{\mathrm{c}}$ & $5,76^{\mathrm{a}}$ & $1,86^{\mathrm{ab}}$ & $92,20^{\mathrm{d}}$ \\
\cline { 2 - 6 } & Италия & $598,1^{\mathrm{c}}$ & $4,70^{\mathrm{d}}$ & $1,92^{\mathrm{ab}}$ & $93,38^{\mathrm{c}}$ \\
\hline \multirow{3}{*}{ III } & Панс Прекос & $468,5^{\mathrm{d}}$ & $3,26^{\mathrm{f}}$ & $1,64^{\mathrm{b}}$ & $95,10^{\mathrm{a}}$ \\
\cline { 2 - 6 } & Матильда & $489,0^{\mathrm{d}}$ & $4,02^{\mathrm{e}}$ & $1,60^{\mathrm{b}}$ & $94,37^{\mathrm{ab}}$ \\
\cline { 2 - 7 } & Мискет гамбургский & $402,0^{\mathrm{e}}$ & $4,89^{\mathrm{cd}}$ & $2,13^{\mathrm{a}}$ & $92,98^{\mathrm{cd}}$ \\
\hline
\end{tabular}

Примечание: a,b,c,d,e,f - степень доказательности при уровне значимости $\alpha=0,05$.

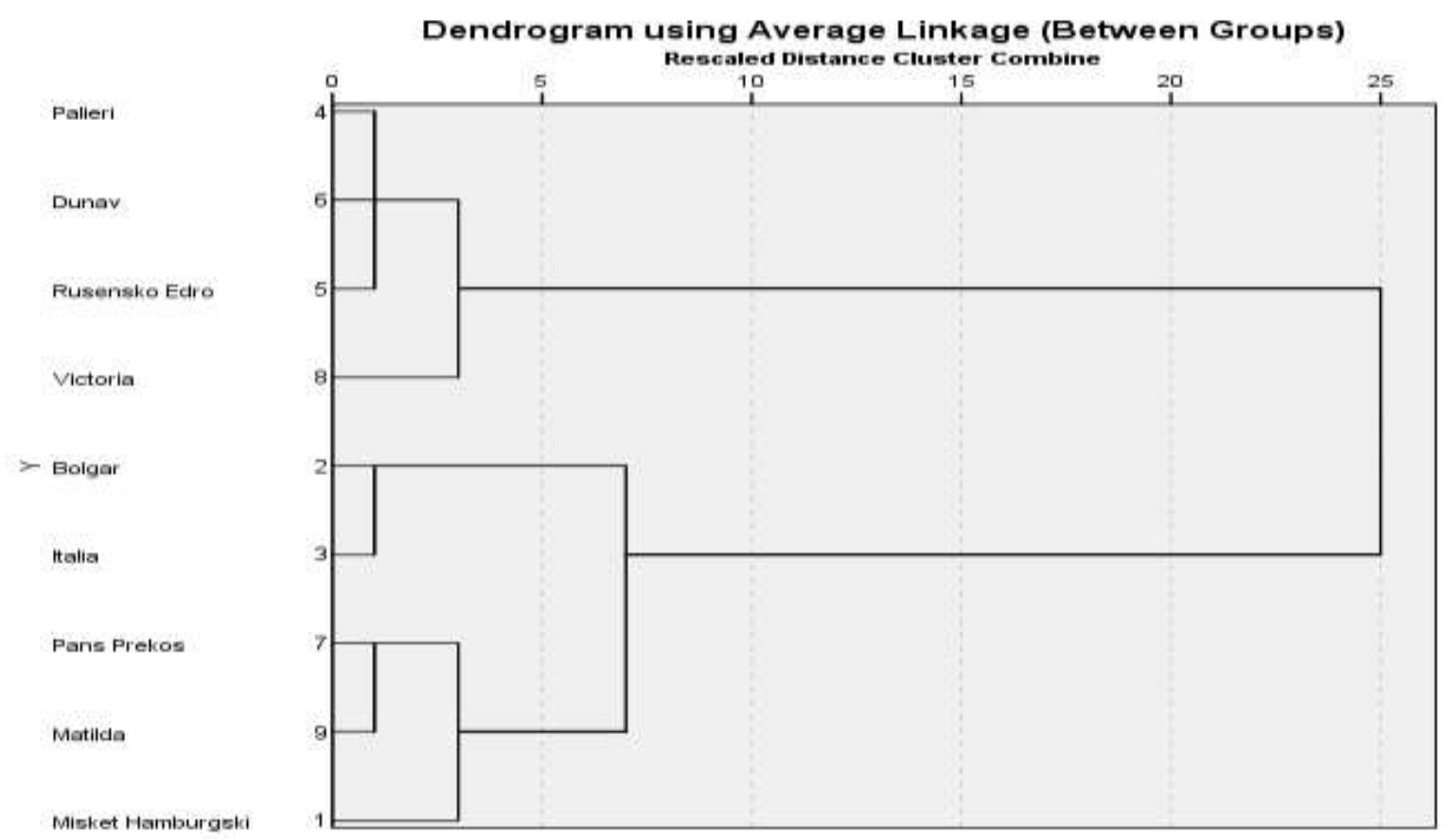

Рис. 2. Дендрограмма - кластеризация исследуемых десертных сортов винограда в зависимости от показателей: масса 100 ягод и структура ягоды 
После обработки экспериментальных данных с помощью факторного анализа показатель «масса 100 ягод», а также показатели, связанные со структурой ягоды, трансформировались до двух факторов. Первый включает массу и объясняет 47 \% общего варьирования, а остальные три составляют второй фактор, который вместе с первым обусловливает 85 \% дисперсии. Эти результаты доказывают, что на генетическую удалённость девяти исследуемых сортов винограда влияние оказывает в наибольшей степени показатель «масса 100 ягод».

Доказано, что самым высоким содержанием сахаров в ягодах среди исследуемых десертных сортов винограда обладает Мискет гамбургский $(16,95 \%)$, за ним идёт сорт Италия (16,33\%), наименьшее их количество у сорта Панс Прекос (15,30 \%) (табл. 5). Самая высокая концентрация титруемых кислот у сортов Италия $(6,79 \mathrm{~g} / \mathrm{dm} 3)$ и Панс Прекос $(6,77 \mathrm{~g} / \mathrm{dm} 3)$, этот показатель самый низкий у сорта Виктория (4,13 g/dm3).

Таблица 5 - Сравнительная оценка исследумых десертных сортов винограда в зависимости от содержания сахаров, титруемых кислот и транспортабельности винограда с помощью однофакторного дисперсионного анализа и теста Duncan

\begin{tabular}{|c|c|c|c|c|c|}
\hline \multirow{2}{*}{$\begin{array}{c}\text { Кластер } \\
\text { № }\end{array}$} & \multirow[b]{2}{*}{ Сорт } & \multirow{2}{*}{$\begin{array}{c}\text { Caxapa, } \\
\%\end{array}$} & \multirow{2}{*}{$\begin{array}{c}\text { Титруемые } \\
\text { кислоты, } \\
\text { g/dm }{ }^{3}\end{array}$} & \multicolumn{2}{|c|}{ Транспортабельность } \\
\hline & & & & $\begin{array}{c}\text { нажим, } \\
\mathrm{g}\end{array}$ & срывание, g \\
\hline \multirow{3}{*}{$\mathrm{I}$} & $\begin{array}{l}\text { Мискет } \\
\text { гамбургский }\end{array}$ & $16,95^{\mathrm{a}}$ & $6,17^{\mathrm{ab}}$ & $1391^{\mathrm{f}}$ & $265^{\mathrm{e}}$ \\
\hline & Панс Прекос & $15,30^{\text {cd }}$ & $6,77^{\mathrm{a}}$ & $1376^{\mathrm{f}}$ & $273^{\mathrm{e}}$ \\
\hline & Матильда & $15,77^{\mathrm{bcd}}$ & $5,57^{\mathrm{bc}}$ & $1358^{\mathrm{f}}$ & $430^{\mathrm{d}}$ \\
\hline \multirow{5}{*}{ II } & Русенско Едро & $15,91^{\mathrm{bc}}$ & $6,13^{\mathrm{b}}$ & $1886^{\mathrm{de}}$ & $478^{\mathrm{c}}$ \\
\hline & Виктория & $15,80^{\mathrm{bcd}}$ & $4,13^{\mathrm{e}}$ & $1961^{\mathrm{cd}}$ & $562^{b}$ \\
\hline & Болгар & $15,83^{\mathrm{bcd}}$ & $5,61^{\mathrm{bc}}$ & $1784^{\mathrm{e}}$ & $560^{\mathrm{b}}$ \\
\hline & Палиери & $15,57^{\mathrm{cd}}$ & $4,80^{\mathrm{d}}$ & $2041^{\mathrm{c}}$ & $655^{\mathrm{a}}$ \\
\hline & Италия & $16,33^{\mathrm{ab}}$ & $6,79^{\mathrm{a}}$ & $2344^{b}$ & $551^{\mathrm{b}}$ \\
\hline III & Дунай & $15,17^{\mathrm{d}}$ & $5,18^{\mathrm{cd}}$ & $3237^{\mathrm{a}}$ & $668^{\mathrm{a}}$ \\
\hline
\end{tabular}

Примечание: a,b,c,d,e,f - степень доказательности при уровне значимости $\alpha=0,05$.

Наиболее устойчив к транспортировке виноград сортов Дунай и Италия, у которых значения показателей «устойчивость при нажиме» и «при срывании» 
составляют 3237 g и 668 g и, соответственно, 2344 g и 551 g. Большой устойчивостью «при срывании» обладает также сорт Палиери (655 g).

Иерархический кластерный анализ, сообразно генетической удалённости исследуемых десертных сортов в зависимости от показателей «содержание сахаров, титруемых кислот» и «транспортабельность винограда», формирует три кластера (рис. 3). Первый включает сорта со сравнительно высоким содержанием сахаров и титруемых кислот и с низкой степенью транспортабельности - Мискет гамбургский, Панс Прекос и Матильда. Второй состоит из сортов Русенско Едро, Виктория, Болгар, Палиери и Италия, имеющих доказанное сходство по высокому содержанию сахаров и титруемых кислот. Последний кластер самостоятельный и включает десертный сорт Дунай, содержащий меньшее количество сахаров и титруемых кислот.

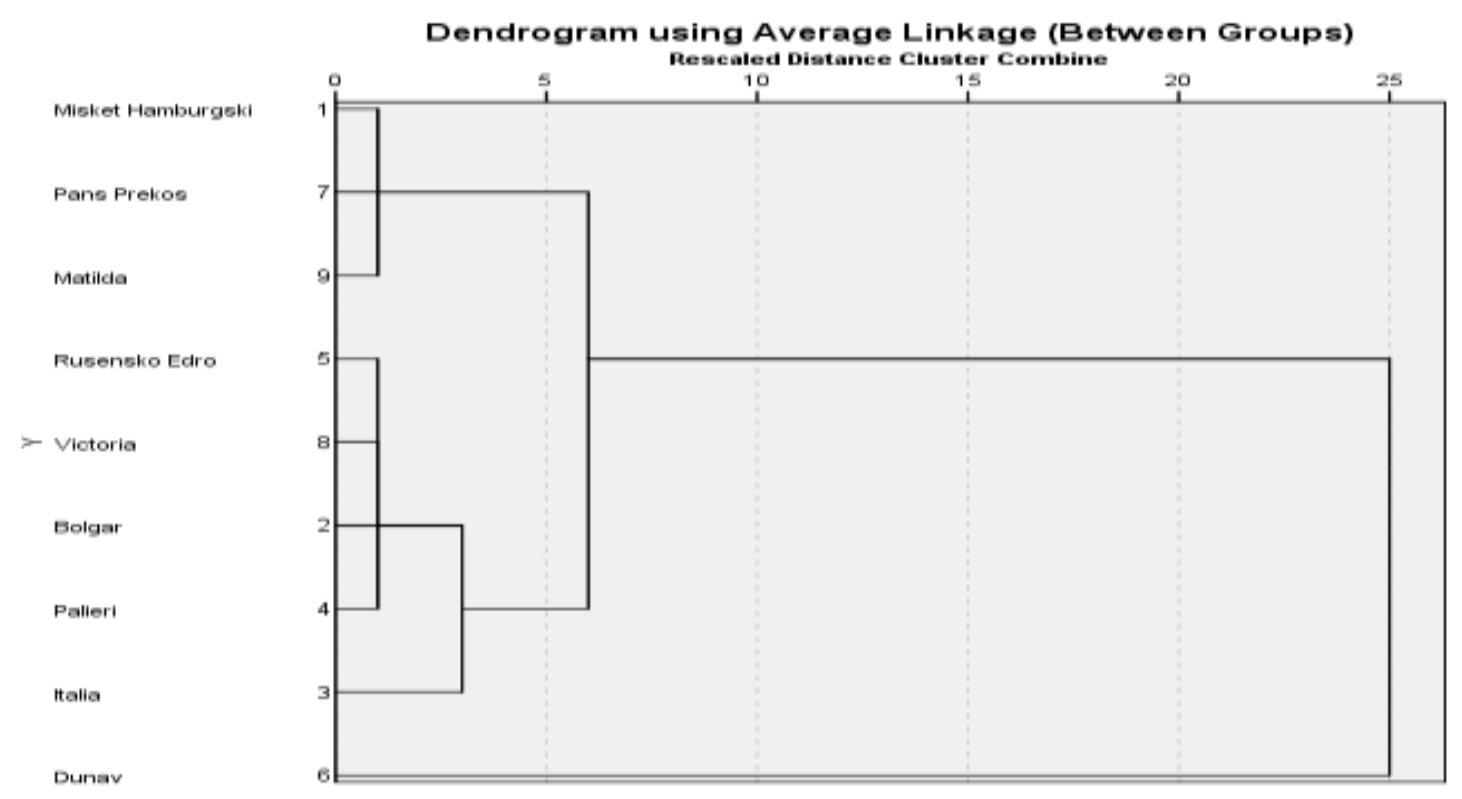

Рис. 3. Дендрограмма - кластеризация исследуемых десертных сортов винограда в зависимости от содержания сахаров, титруемых кислот и транспортабельности винограда

Результаты факторного анализа на базе этих четырёх показателей показывают, что они трансформируются до одного фактора, объясняющего 53 \% общего варьирования, причём преобладающее влияние имеет показатель «срывание», ввиду его максимального факторного веса $(0,826)$, значительно превышающего этот же вес остальных показателей этой группы. 
Самый большой урожай даёт сорт Дунай (11,991 kg с одного виноградного куста, $3132 \mathrm{~kg} \mathrm{c} 10$ аров), следующую строчку занимает сорт Виктория (11,263 kg с одного куста, $2928 \mathrm{~kg}$ с 10 аров) (табл. 6).

Таблица 6 - Сравнительная оценка исследуемых десертных сортов винограда в зависимости от урожая и структуры грозди с помощью однофакторного дисперсионного анализа и теста Duncan

\begin{tabular}{|c|c|c|c|c|c|c|}
\hline $\begin{array}{c}\text { Кластер } \\
\text { № }\end{array}$ & Сорт & \begin{tabular}{|c|} 
Урожай \\
с одного \\
виноградного \\
куст, \\
kg \\
\end{tabular} & $\begin{array}{c}\text { Урожай } \\
\text { с } 10 \text { акров, } \\
\text { kg }\end{array}$ & $\begin{array}{c}\text { Масса } \\
\text { грозди, } \\
\text { g }\end{array}$ & $\begin{array}{c}\text { Гребни, } \\
\%\end{array}$ & $\begin{array}{c}\text { Ягоды, } \\
\%\end{array}$ \\
\hline \multirow{3}{*}{ I } & Дунай & $11,991^{\mathrm{a}}$ & $3132^{\mathrm{a}}$ & $470^{\mathrm{b}}$ & $2,40^{\mathrm{ab}}$ & $97,60^{\text {abc }}$ \\
\hline & Панс Прекос & $9,280^{\mathrm{b}}$ & $2413^{b}$ & $332^{\mathrm{de}}$ & $2,88^{\mathrm{a}}$ & $97,12^{\mathrm{c}}$ \\
\hline & Матильда & $9,766^{\mathrm{b}}$ & $2539^{b}$ & $388^{\mathrm{cd}}$ & $2,79^{\mathrm{a}}$ & $97,21^{\mathrm{bc}}$ \\
\hline \multirow{2}{*}{ II } & $\begin{array}{l}\text { Русенско } \\
\text { Едро }\end{array}$ & $9,633^{\mathrm{b}}$ & $2504^{\mathrm{b}}$ & $409^{\mathrm{bc}}$ & $2,19^{\mathrm{b}}$ & $97,81^{\mathrm{a}}$ \\
\hline & Виктория & $11,263^{\mathrm{a}}$ & $2928^{a}$ & $563^{\mathrm{a}}$ & $2,17^{\mathrm{b}}$ & $97,83^{\mathrm{a}}$ \\
\hline \multirow{2}{*}{ III } & $\begin{array}{l}\text { Мискет } \\
\text { гамбургский }\end{array}$ & $6,036^{\mathrm{e}}$ & $1569^{\mathrm{e}}$ & $304^{\mathrm{e}}$ & $2,08^{b}$ & $97,92^{\mathrm{a}}$ \\
\hline & Италия & $5,960^{\mathrm{e}}$ & $1551^{\mathrm{e}}$ & $391^{\text {cd }}$ & $2,35^{\mathrm{ab}}$ & $97,65^{\mathrm{abc}}$ \\
\hline \multirow[b]{2}{*}{ IV } & Болгар & $8,237^{c}$ & $2141^{\mathrm{c}}$ & $403^{\mathrm{bc}}$ & $2,37^{\mathrm{ab}}$ & $97,63^{\mathrm{ab}}$ \\
\hline & Палиери & $7,174^{\mathrm{d}}$ & $1865^{\mathrm{d}}$ & $330^{\text {de }}$ & $2,59^{\mathrm{ab}}$ & $97,41^{\mathrm{abc}}$ \\
\hline
\end{tabular}

Примечание: a,b,c,d,e - степень доказательности при уровне значимости $\alpha=0,05$.

Самая тяжелая гроздь у сорта Виктория (563 g), а самая легкая - у сорта Мискет гамбургский (304 g). Учитывая структуру грозди, самые маленькие в процентном соотношении гребни у сорта Мискет гамбургский (2,08 \%), а самые большие - у сорта Пан Прекос (2,88 \%), что означает, что процент ягод у этих же сортов - 97,92 \%, и 97,12 \%, соответственно. Следует отметить, что выявлены небольшие отличия между отдельными сортами по этому показателю.

Применённый иерархический кластерный анализ установил, что исследуемые десертные сорта винограда группируются в четыре кластера в зависимости от их урожайности и структуры грозди (рис. 4).

Первые два кластера состоят из высокопродуктивных сортов Дунай, Панс Прекос, Матильда, Русенско Едро и Виктория, имеющих доказанные отличия в 
структуре грозди. Третий включает сорта Мискет гамбургский и Италия - менее продуктивные, в последний входят Болгар и Палиери.

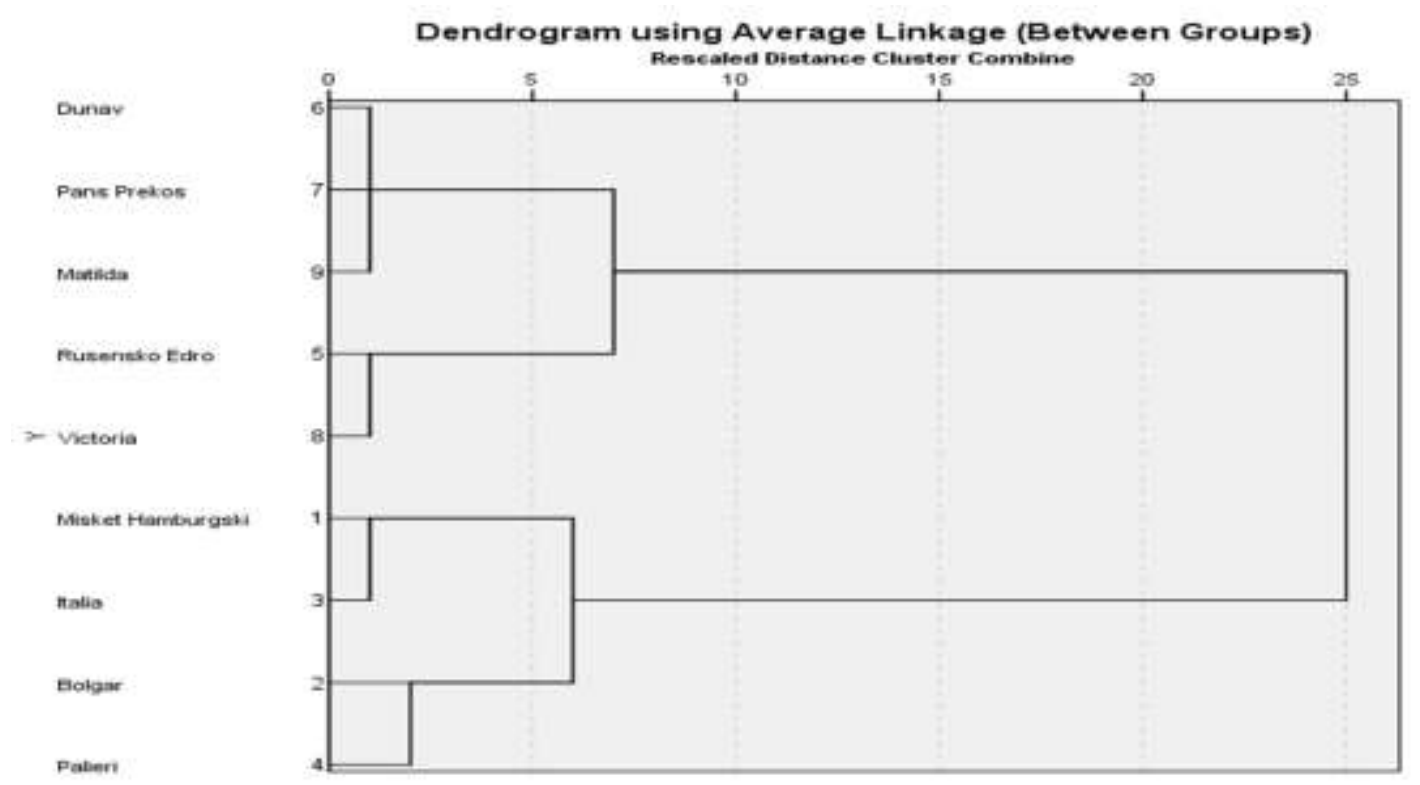

Фиг. 4. Дендрограмма - кластеризация исследуемых десертных сортов винограда в зависимости от урожая и структуры грозди

Факторный анализ доказывает, что более существенное влияние на разделение сортов по группам оказывает урожайность винограда (51 \%), в меньшей степени - структура грозди (39 \%), что определяет трансформирование пяти показателей до двух факторов.

Bbыводы. Математически доказано, что коэффициент действительной плодоносности у побегов, развившихся на сучке замещения и на плодовой стрелке, имеет наибольшие значения у сорта винограда Виктория, наименьшие - у сортов Панс Прекос и Италия. Процент плодовых побегов из угловых и зимних глазков на сучке замещения наиболее высокий у сорта Матильда, низкий - у сорта Дунай, а развившихся из зимних глазков - у сортов Виктория и Италия. Высокий процент развитых побегов из угловых глазков на сучке замещения у сорта Русенско Едро, из зимних глазков - у сорта Панс Прекос.

В варианте «плодовая стрелка» наибольшее количество побегов, развившихся из угловых глазков, имеет сорт Палиери, наименьшее - сорта Италия и Мискет гамбургский. Иерархический кластерный анализ группирует 
Плодоводство и виноградарство Юга России № 61(1), 2020 г.

исследуемые десертные сорта винограда в зависимости от этой группы показателей в три кластера. Результаты показывают, что Виктория и Матильда генетически наиболее удалённые от остальных сортов.

Показано, что наибольшей массой 100 ягод обладают сорта Палиери, Дунай и Русенско Едро, наименьшей - Мискет гамбургский. Доля кожиц в ягодах высокая у сорта Болгар, низкая - у сорта Дунай. Количество семян большее у сорта Мискет гамбургский, меньшее - у сорта Виктория. Самый большой мезокарпий отмечен у ягод сорта Панс Прекос. Исследуемые сорта сгруппированы в три кластера на базе их генетической удалённости по показателям «масса 100 ягод» и «структура ягоды», причём сорта Палиери, Дунай и Русенско Едро наиболее удалённые от сортов Панс Прекос, Матильда и Мискет гамбургский.

Установлено, что наиболее высокое содержание сахаров имеет сорт Мискет гамбургский, за ним идёт сорт Италия, а наименьшее его количество у сорта Панс Прекос. Высокая концентрация титруемых кислот у сортов Италия и Панс Прекос, низкая - у сорта Виктория. Самый устойчивый к транспортировке виноград сортов Дунай и Италия. Иерархический кластерный анализ, сообразно генетической удалённости исследуемых сортов, в зависимости от показателей «содержание сахаров, титруемых кислот» и «транспортабельность винограда», формирует три кластера. Сорт Дунай выделяется как генетически наиболее удалённый от остальных из-за низкого содержания сахаров и титруемых кислот, и вместе с тем он наиболее транспортабельный.

По урожайности с одного куста и с 10 аров выделились сорта Дунай и Виктория; самая тяжёлая гроздь у сорта Виктория; а самая лёгкая - у Мискета гамбургского; процент ягод наиболее высокий у сортов Мискет гамбургский и Пан Прекос, а отличия между отдельными сортами по этому показателю минимальные. По урожайности и структуре грозди кластерный анализ группирует исследуемые десертные сорта в четыре кластера.

Ввиду своего максимального факторного веса из всех показателей в первой группе коэффициент плодоносности и процент плодовых побегов 
Плодоводство и виноградарство Юга России № 61(1), 2020 г.

оказывают наиболее сильное воздействие на генетическую удалённость исследуемых сортов, во второй группе - масса 100 ягод. У показателя «срывание» доминирующее влияние на распределение сортов в кластеры проявляется в третьей группе. В четвертой группе самый ощутимый эффект, определяющий дифференциацию сортов, даёт урожай винограда. Полученные результаты могут быть использованы в агротехнике и селекционной работе с десертными сортами винограда.

\section{Литература}

1. Българска Ампелография, 1990. Обща Ампелография, София, том I, 296 с.

2. Българска Ампелография, 2010. Частна Ампелография, София, том II, 280 с.

3. Българска Ампелография, 2015. Частна Ампелография, София, том III, 274 с.

4. Катеров К., Т. Начев, 1990. Възникване и развитие на лозарските райони в България. Лозарство и винарство, 3, 4-8.

5. Пенков М., 2009. Микрорайониране на лозарството в България. Лозарски тероар. Лозарство и винарство, 3, 23-25.

6. Стоев К. и др., 1960. Райониране на лозарството в България. Земиздат, София, 168 с.

7. Иванов М., 2016. Хибридизацията в селекцията на лозата. Монография. Академично издателство на Аграрен университет-Пловдив, 178 с.

8. Лазаров И., В. Костова, Б. Кирилов, 2004. Сортове лози българска селекция. София, $184 \mathrm{c.}$

9. Лазаров И., 2015. Сортове лози българска селекция. Част втора. Издателство «ПРОПЕЛЕР», София, $116 \mathrm{c.}$

10. Наков, 3., 2013. Приложение на клоновата селекция при сорт Каберне Совиньон. Дисертация, 189 с.

11. Симеонов И., 2014. Клонова селекция при лозовите сортове Димят и Мискет врачански. Дисертация, Пловдив, $231 \mathrm{c.}$

12. Ненько Н.И., Ильина И.А., Петров В.С., Сундырева М.А., Запорожец Н.М., Киселева Г.К., Схаляхо Т.В. Устойчивость сортов винограда к засухе // Вестник Российской сельскохозяйственной науки. Москва, 2019. №5. C. 40-45. DOI: 10.30850/vrsn/2019/5/40-45. URL: https://elibrary.ru/item.asp?id=40926664. Дата публикации: 06.11.2019. Двухлетний импакт-фактор РИНЦ - 0,679

13. Ройчева А., 2019. Ефективност и конкурентност на българското лозарство. Дисертация, 265 с., Пловдив.

14. Петров В.С., Алейникова Г.Ю., Павлюкова Т.П., Ненько Н.И., Сундырева М.А. Агробиологические, физиолого-биохимические и технологические особенности винограда сорта Рислинг рейнский в условиях изменяющегося климата юга России // «Магарач». Виноградарство и виноделие, Ялта, 2019. Т. 21(3). С. 204-210. DOI 10.35547/iM.2019.21.3.004 URL: http://magarach-journal.ru/index.php/magarach/article/ view/79/44 https://elibrary.ru/item.asp?id=39548787 дата публикации 23. 09. 2019г. двухлетний импакт-фактор РИНЦ - 0,967

15. Дергачёв Д. В., Ларькина М. Д., Петров В.С., Панкин М.И. Особенности вегетации интродуцированного сорта винограда Кёхо в стрессовых погодных условиях умеренно континентального климата юга России // «Магарач» Виноградарство и виноделие. Ялта, 2019. Т.21 (3). C. 223-228. DOI 10.35547/IM.2019.21.3.007 URL: https://elibrary.ru/ item.asp?id=39548791 Дата публикации: 20. 08. 2019г. двухлетний импакт-фактор РИНЦ - 0,967 
16. М.Д. Ларькина, Д.В. Дергачев, В.С. Петров, М.И. Панкин, 2019. Особенности на вегетацията на отделни лозови сортове при неблагоприятни (стресови) метеорологични условия на умерения континентален климат в Южна Русия, Лоза и вино, 1, 10-18,

17. Field A., 2009. Discovering statistics using SPSS, SAGE Publications Ltd, London, 177 p.

18. Ho R., 2006. Handbook of univariate and multivariate data analysis and interpretation with SPSS, Taylot \& Francis Group, New York, 189 p.

19. Sarwono J., 2017. Correlation and regression: How to use in data analysis using IBM SPSS and Eviews, 12 p.

\section{References}

1. B"lgarska Ampelografiya, 1990. Obshcha Ampelografiya, Sofiya, tom I, 296 s.

2. B"lgarska Ampelografiya, 2010. Chastna Ampelografiya, Sofiya, tom II, $280 \mathrm{~s}$.

3. B"lgarska Ampelografiya, 2015. Chastna Ampelografiya, Sofiya, tom III, 274 s.

4. Katerov K., T. Nachev, 1990. V"znikvane i razvitie na lozarskite rajoni v B"lgariya. Lozarstvo i vinarstvo, 3, 4-8.

5. Penkov M., 2009. Mikrorajonirane na lozarstvoto v B"lgariya. Lozarski teroar. Lozarstvo i vinarstvo, 3, 23-25.

6. Stoev K. i dr., 1960. Rajonirane na lozarstvoto v B"lgariya. Zemizdat, Sofiya, $168 \mathrm{~s}$.

7. Ivanov M., 2016. Hibridizaciyata v selekciyata na lozata. Monografiya. Akademichno izdatelstvo na Agraren universitet-Plovdiv, $178 \mathrm{~s}$.

8. Lazarov I., V. Kostova, B. Kirilov, 2004. Sortove lozi b"lgarska selekciya. Sofiya, 184 s.

9. Lazarov I., 2015. Sortove lozi b"lgarska selekciya. Chast vtora. Izdatelstvo "PROPELER", Sofiya, $116 \mathrm{~s}$.

10. Nakov, Z., 2013. Prilozhenie na klonovata selekciya pri sort Kaberne Sovin'on. Disertaciya, $189 \mathrm{~s}$.

11. Simeonov I., 2014. Klonova selekciya pri lozovite sortove Dimyat i Misket vrachanski. Disertaciya, Plovdiv, $231 \mathrm{~s}$.

12. Nen'ko N.I., Il'ina I.A., Petrov V.S., Sundyreva M.A., Zaporozhec N.M., Kiseleva G.K., Skhalyaho T.V. Ustojchivost' sortov vinograda k zasuhe // Vestnik Rossijskoj sel'skohozyajstvennoj nauki. Moskva, 2019. №5. S. 40-45. DOI: 10.30850/vrsn/2019/5/40-45. URL: https://elibrary.ru/item.asp?id=40926664. Data publikacii: 06.11.2019. Dvuhletnij impakt-faktor RINC - 0,679

13. Rojcheva A., 2019. Efektivnost i konkurentnost na b"lgarskoto lozarstvo. Disertaciya, 265 s., Plovdiv.

14. Petrov V.S., Alejnikova G.Yu., Pavlyukova T.P., Nen'ko N.I., Sundyreva M.A. Agrobiologicheskie, fiziologo-biohimicheskie i tekhnologicheskie osobennosti vinograda sorta Risling rejnskij v usloviyah izmenyayushchegosya klimata yuga Rossii // «Magarach». Vinogradarstvo i vinodelie, Yalta, 2019. T. 21(3). S. 204-210. DOI 10.35547/iM.2019.21.3.004 URL: http://magarach-journal.ru/index.php/magarach/article/ view/79/44 https://elibrary.ru/ item.asp?id=39548787 data publikacii 23. 09. 2019g. dvuhletnij impakt-faktor RINC - 0,967

15. Dergachyov D. V., Larkina M. D., Petrov V.S., Pankin M.I. Osobennosti vegetacii introducirovannogo sorta vinograda Kyoho v stressovyh pogodnyh usloviyah umerenno kontinental'nogo klimata yuga Rossii // «Magarach» Vinogradarstvo i vinodelie. Yalta, 2019. T.21 (3). S. 223-228. DOI 10.35547/IM.2019.21.3.007 URL: https://elibrary.ru/item.asp?id=39548791 Data publikacii: 20. 08. 2019g. dvuhletnij impakt-faktor RINC - 0,967

16. M.D. Lar'kina, D.V. Dergachev, V.S. Petrov, M.I. Pankin, 2019. Osobennosti na vegetaciyata na otdelni lozovi sortove pri neblagopriyatni (stresovi) meteorologichni usloviya na umereniya kontinentalen klimat v Yuzhna Rusiya, Loza i vino, 1, 10-18,

17. Field A., 2009. Discovering statistics using SPSS, SAGE Publications Ltd, London, 177 p.

18. Ho R., 2006. Handbook of univariate and multivariate data analysis and interpretation with SPSS, Taylot \& Francis Group, New York, 189 p.

19. Sarwono J., 2017. Correlation and regression: How to use in data analysis using IBM SPSS and Eviews, $12 \mathrm{p}$. 